九州大学学術情報リポジトリ

Kyushu University Institutional Repository

\title{
Varietal Resistance of Soybean CuItivars to Xanthomonas campestris pv. glycines Strains Isolated from Japan and Thai land
}

Jainkittivong, Anong

Plant Pathology Laboratory, Faculty of Agriculture, Kyushu University

Mat suyama, Nobuaki

Plant Pathology Laboratory, Faculty of Agriculture, Kyushu University

Wakimoto, Satoshi

Plant Pathology Laboratory, Faculty of Agriculture, Kyushu University

https://doi.org/10.5109/23885

出版情報 : 九州大学大学院農学研究院紀要. 34 (1/2)，pp.31-35，1989-11. Kyushu University バージョン：

権利関係 : 


\title{
Varietal Resistance of Soybean Cultivars to Xanthomonas campestris pv. glycines Strains Isolated from Japan and Thailand
}

\author{
Anong Jainkittivong, Nobuaki Matsuyama and Satoshi Wakimoto \\ Plant Pathology Laboratory, Faculty of Agriculture, \\ Kyushu University 46-01, Fukuoka 812, Japan
}

(Received March, 14, 1989)

\begin{abstract}
Fourty-five soybean cultivars were inoculated with six strains of Xanthomonas campestris pv. glycines collected from Japan and Thailand to investigate their resistance. The degree of resistance was greatly varied depending upon bacterial strains inoculated, suggesting that resistance of soybean cultivars to X. c. pv. glycines is controlled by complicated various genes. Soybean cultivars belonging to the tentative group I were resistant to the majority of the bacterial strains. However, none of the cultivars were resistant to all bacterial strains Used.
\end{abstract}

\section{INTRODUCTION}

Varietal resistance of soybean cultivars was first reported by Lehman and Woodside in 1929. Hartwig and Lehman (1951) analized genes for resistance of soybean cultivar Clemson Non Shatter (CNS) to bacterial pustule by inoculating pathogenic bacterium to $\mathrm{F}_{2}$ and $\mathrm{F}_{3}$ progenies of the hybrid. They concluded that resistance is recessive and controlled by single major gene. These workers, however, did not have any considerations about differentiation of the bacterium in pathogenicity. Patel et al. (1972) reported that all of the soybean cultivars used in their experiment exhibited similar resistance to X. phaseoli var. sojensis and suggested that there are no pathogenic differentiation in the pustule organism in India. Jindal et al. (1981) confirmed that X. c. pv. vignicola and pv. phaseoli strains showed differentiation in pathogenicity whereas $X$. c. pv. glycines strains did not.

In this study, varietal difference in resistance of soybean cultivars collected from Japan and Thailand were examined by inoculating six strains of X. c. pv. glycines.

\section{MATERIALS AND METHODS}

\section{Bacterial strains}

The bacterial strains used were listed in Table 1. These strains were different in pathogenicity as reported previously (Jainkittivong et al., 1989). Each strain was cultured on PSA slant medium at $25 \mathrm{C}$ for 24-36 hr. The culture was suspended in sterilized distilled water and $\mathrm{OD}$ was adjusted to 1.0 at $660 \mathrm{~nm}$ so as to give bacterial concentration of about $3 \times 10^{8} \mathrm{cfu} / \mathrm{ml}$. 
Soybean cultivars

Twenty-nine soybean cultivars from Japan and 16 cultivars from Thailand were used. Three seeds of each soybean cultivar were sown in a pot $(10 \mathrm{~cm}$ diam. $)$ filled with a mixture of pulverized soil and grown in a greenhouse at 20-25 C.

\section{Inoculation}

Fully-expanded second trifoliate leaves of 20 days old plants were inoculated with bacterial suspension by spraying.

Two hr after inoculation, the plants were transferred to an incubator (RH $100 \%$, 28-30 C). After $24 \mathrm{hr}$ of incubation, the plants were moved to the greenhouse (20-25 C). Early symptom of minute yellow spots usually appeared in several days after inoculation and they developed into pustules in a following few days.

In the highly compatible host-parasite combinations, many pustules with halo were developed on the leaves and coalesced forming irregular brown patches. Diseased leaves turned yellow and defoliated later.

In the less compatible combinations, a few, isolated, minute, flat and slowly developing spots appeared without producing haloes. In the incompatible combinations, no spots appeared. In the latter two combinations neither yellowing nor defoliation occurred.

Disease severity was assessed 3, 5, 7 and 15 days after inoculation as reported in the previous paper (Jainkittivong et al., 1989). To simplify the expression of the results, R (resistant) was given for the grade of resistance -- $\#$ and $\mathrm{S}$ (susceptible) was for $\mathrm{H} \sim$ Wl.

Every experiment was replicated twice.

\section{RESULTS AND DISCUSSION}

The results shown in Table 2 suggest that disease incidence of cultivars was much varied depending upon bacterial strains of $X$. c. pv. glycines inoculated. Only eight cultivars (Harosoy, Clark 63, TGX 297-192 C, TGX 713-06 D, TGX 742-01 D, Shirosennari, Shin 4 and Wakajima) were resistant to bacterial strain 301-1, seven cultivars (Harosoy, Clark 63, TGX 297-192 C, TGX 713-06 D, TGX 742-01 D, Kinsei 1 and OCB) were resistant to bacterial strain 045-1 and six cultivars (TGX 330-054 D, TGX 342356 D, Shirome, Fukuyutaka, Papillon and Tamahomare) were resistant to bacterial strain S-12. While, most of the cultivars other than the nine (OCB, M 90, Akiyoshi, S. J. 2, Papillon, Tamahomare, S. J. 5, S. J. 4 and Akazaya) were resistant to bacterial

Table 1. Bacterial strains used.

\begin{tabular}{|c|c|c|c|}
\hline $\begin{array}{l}\text { Xanthomonas campestris } \\
\text { pv. glycines strain }\end{array}$ & \multicolumn{2}{|l|}{ Place } & Year \\
\hline $045-1$ & Saraburi & (Thailand) & 1980 \\
\hline $046-3$ & $n$ & $(1 /)$ & $n$ \\
\hline 054-1 & Phitsanulok & $(1)$ & $m$ \\
\hline $301-1$ & Cheingmai & $(1)$ & 1981 \\
\hline $\mathrm{Ku}-1$ & Bangkhen & $(11)$ & 1982 \\
\hline $\mathrm{s}-12$ & Fukuoka & ( Japan ) & 1986 \\
\hline
\end{tabular}


Table 2. Varietal resistance of soybean cultivars to $X$ anthomonas campestris pv. glycines strains.

\begin{tabular}{|c|c|c|c|c|c|c|c|c|}
\hline \multirow{2}{*}{\multicolumn{2}{|c|}{ No. $\begin{array}{c}\text { Soybean } \\
\text { cultivars }\end{array}$}} & \multicolumn{6}{|c|}{ Bacterial strain } & \multirow{2}{*}{$\begin{array}{l}\text { Tentative } \\
\text { grouping }\end{array}$} \\
\hline & & 054-I & $301-1$ & I & $\mathrm{Ku}-\mathrm{I}$ & $046-3$ & S - 12 & \\
\hline 1. & Harosoy & $\mathrm{R}$ & $\mathrm{R}$ & $\mathrm{R}$ & $\mathrm{R}$ & $\mathrm{R}$ & $\mathbf{S}$ & \\
\hline 2. & Clark 63 & $\mathrm{R}$ & $\mathrm{R}$ & $\mathrm{R}$ & $\mathrm{R}$ & $\mathrm{R}$ & S & I \\
\hline 3. & TGX $297-192 \mathrm{C}$ & $\mathrm{R}$ & $\mathrm{R}$ & $\mathrm{R}$ & $\mathrm{R}$ & $\mathrm{R}$ & $\mathbf{S}$ & _ \\
\hline 4. & TGX 713-06D & $\mathrm{R}$ & $\mathrm{R}$ & $\mathrm{R}$ & s & $\mathrm{R}$ & $\mathrm{S}$ & \\
\hline 5. & TGX $742-01 \mathrm{D}$ & $\mathrm{R}$ & $\mathrm{R}$ & $\mathrm{R}$ & $\mathrm{s}$ & $\mathrm{s}$ & $\mathrm{S}$ & \\
\hline 6. & Shirosennari & $\mathrm{R}$ & $\mathrm{R}$ & $\mathrm{s}$ & $\mathrm{R}$ & $\mathrm{s}$ & $\mathrm{s}$ & H \\
\hline 7. & Shin 4 & $\mathrm{R}$ & $\mathrm{R}$ & S & $\mathrm{R}$ & $\mathrm{s}$ & S & II \\
\hline 8. & Wakajima & $\mathrm{R}$ & $\mathrm{R}$ & s & s & $\mathrm{s}$ & $\mathrm{s}$ & \\
\hline 9. & Kinsei 1 & $\mathrm{R}$ & $\mathrm{s}$ & $\mathrm{R}$ & $\mathrm{R}$ & $\mathrm{R}$ & $\mathrm{S}$ & \\
\hline 10. & TGX $330-054 \mathrm{D}$ & $\mathrm{R}$ & $\mathrm{s}$ & $\mathrm{s}$ & $\mathrm{R}$ & $\mathrm{R}$ & $\mathrm{R}$ & \\
\hline 11. & TGX $307-047 \mathrm{D}$ & $\mathrm{R}$ & $\mathrm{S}$ & $\mathrm{s}$ & $\mathrm{R}$ & $\mathrm{s}$ & $\mathrm{s}$ & $\neg$ \\
\hline 12. & Raikou & $\mathrm{R}$ & $\mathrm{s}$ & $\mathrm{s}$ & $\mathrm{R}$ & $\mathrm{s}$ & $\mathrm{s}$ & \\
\hline 13. & Ouhoujyu & $\mathrm{R}$ & $\mathrm{s}$ & $\mathrm{s}$ & $\mathrm{R}$ & $\mathrm{S}$ & $\mathrm{S}$ & \\
\hline 14. & Mutsushiratama & $\mathrm{R}$ & $\mathrm{s}$ & $\vec{s}$ & $\mathrm{R}$ & $\mathrm{s}$ & $\mathrm{s}$ & 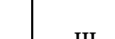 \\
\hline 15. & Enrei & $\mathrm{R}$ & $\mathrm{s}$ & $\mathrm{s}$ & $\mathrm{R}$ & $\mathrm{s}$ & $\mathrm{s}$ & $1 \mathrm{II}$ \\
\hline 16. & Hyuga & $\mathrm{R}$ & $\mathrm{S}$ & $\mathrm{s}$ & $\mathrm{R}$ & $\mathrm{s}$ & $\mathrm{s}$ & \\
\hline 17. & Misuzudaizu & $\mathrm{R}$ & $\mathrm{S}$ & $\mathrm{s}$ & $\mathrm{R}$ & $\mathrm{s}$ & $\mathrm{s}$ & \\
\hline 18. & Chiyohime & $\mathrm{R}$ & $\mathrm{S}$ & $\mathrm{s}$ & $\mathrm{R}$ & $\mathrm{s}$ & $\mathrm{s}$ & ـ \\
\hline 19. & TGX 342-356D & $\mathrm{R}$ & s & $\mathrm{s}$ & $\mathrm{s}$ & $\mathrm{R}$ & $\mathrm{R}$ & \\
\hline 20. & Shirome & $\mathrm{R}$ & $\mathrm{S}$ & $\mathrm{s}$ & $\mathrm{s}$ & $\mathrm{R}$ & $\mathrm{R}$ & $\neg \mathrm{IV}$ \\
\hline 21. & 81-I-032 & $\mathrm{R}$ & $\mathrm{S}$ & $\mathrm{s}$ & $\mathrm{s}$ & $\mathrm{R}$ & $\mathrm{s}$ & \\
\hline 22. & Shiromame & $\mathrm{R}$ & $\mathrm{s}$ & $\mathrm{s}$ & $\mathrm{s}$ & $\mathrm{R}$ & $\mathrm{s}$ & V \\
\hline 23. & Nanbushirome & $\mathrm{R}$ & $\mathrm{s}$ & $\mathrm{s}$ & $\mathrm{s}$ & $\mathrm{R}$ & $\mathrm{s}$ & V \\
\hline 24. & Koganedaizu & $\mathrm{R}$ & $\mathrm{S}$ & $\mathrm{s}$ & $\mathrm{s}$ & $\mathrm{R}$ & $\mathrm{s}$ & ] \\
\hline 25. & Fukuyutaka & $\mathrm{R}$ & $\mathrm{S}$ & $\mathrm{s}$ & $\mathrm{s}$ & $\mathrm{s}$ & $\mathrm{R}$ & \\
\hline 26. & 81-1-113 & $\mathrm{R}$ & $\mathrm{S}$ & $\mathrm{s}$ & $\mathrm{s}$ & $\mathrm{s}$ & $\mathrm{s}$ & 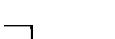 \\
\hline 27. & Tamanishiki & $\mathrm{R}$ & $\mathrm{S}$ & $\mathrm{s}$ & $\mathrm{s}$ & $\mathrm{s}$ & $\mathrm{s}$ & \\
\hline 28. & Tottorishiradaizu & $\mathrm{R}$ & $\mathrm{S}$ & $\mathrm{s}$ & $\mathrm{s}$ & $\mathrm{s}$ & $\mathrm{s}$ & \\
\hline 29. & Oguradaizu & $\mathrm{R}$ & $\mathrm{S}$ & $\mathrm{s}$ & $\mathrm{s}$ & $\mathrm{s}$ & $\mathrm{s}$ & \\
\hline 30. & Fujimusume & $\mathrm{R}$ & $\mathrm{S}$ & $\mathrm{s}$ & $\mathrm{s}$ & $\mathrm{s}$ & $\mathrm{s}$ & \\
\hline 31. & Udadaizu & $\mathrm{R}$ & $\mathrm{S}$ & $\mathrm{s}$ & $\mathrm{s}$ & $\mathrm{s}$ & $\mathrm{s}$ & VI \\
\hline 32. & A somusume & $\mathrm{R}$ & S & $\mathrm{s}$ & $\mathrm{s}$ & $\hat{s}$ & $\mathrm{~s}$ & \\
\hline 33. & Tamahikari & $\mathrm{R}$ & $\mathrm{S}$ & $\mathrm{s}$ & $\mathrm{s}$ & $\mathrm{s}$ & $\mathrm{s}$ & \\
\hline 34. & Nakasennari & $\mathrm{R}$ & $\mathrm{s}$ & $\mathrm{s}$ & $\mathrm{s}$ & $\mathrm{s}$ & $\mathrm{s}$ & \\
\hline 35. & Hougyoku & $\mathrm{R}$ & $\mathrm{s}$ & $\mathrm{s}$ & $\mathrm{s}$ & $\hat{s}$ & $\hat{\mathrm{s}}$ & \\
\hline 36. & Bonminori & $\mathrm{R}$ & $\mathrm{S}$ & $\mathrm{s}$ & $\mathrm{s}$ & $\mathrm{s}$ & $\mathrm{S}$ & \\
\hline 37. & OCB & $\mathrm{s}$ & $\mathrm{s}$ & $\mathrm{R}$ & $\mathrm{R}$ & $\mathrm{R}$ & $\mathrm{s}$ & \\
\hline 38. & M 90 & $\mathrm{~s}$ & $\mathrm{~S}$ & $\mathrm{~s}$ & $\mathrm{R}$ & $\mathrm{R}$ & $\mathrm{S}$ & \\
\hline 39. & Akiyoshi & $\mathrm{s}$ & $\mathrm{s}$ & $\mathrm{s}$ & $\mathrm{R}$ & $\mathrm{R}$ & $\mathrm{S}$ & J VII \\
\hline 40. & S. J. 2 & $\mathrm{~s}$ & $\mathrm{~S}$ & $\mathrm{~s}$ & $\mathrm{~s}$ & $\mathrm{R}$ & $\mathrm{S}$ & \\
\hline 41. & Papillon & $\mathrm{s}$ & $\mathrm{S}$ & $\mathrm{s}$ & $\mathrm{s}$ & $\mathrm{s}$ & $\mathrm{R}$ & $\neg \quad$ yII \\
\hline 42. & Tamahomare & $\mathrm{s}$ & $\mathrm{S}$ & $\mathrm{s}$ & $\mathrm{s}$ & $\mathrm{s}$ & $\mathrm{R}$ & 」 VIII \\
\hline 43. & S. J. 5 & $\mathrm{~s}$ & $\mathrm{~S}$ & $\mathrm{~s}$ & $\mathrm{~s}$ & $\mathrm{~s}$ & $\mathrm{~s}$ & 1 \\
\hline 44. & S. J. 4 & $\mathrm{~s}$ & $\mathrm{~S}$ & $\mathrm{~s}$ & $\mathrm{~s}$ & $\mathrm{~s}$ & s & IX \\
\hline 45. & Akazaya & $\mathrm{s}$ & $\mathrm{S}$ & $\mathrm{s}$ & $\mathrm{s}$ & $\mathrm{s}$ & s & . \\
\hline
\end{tabular}

strain 054-1.

Among 45 cultivars tested, only four (Harosoy, Clark 63, TGX 297-192 C and TGX 713-06 D) were resistant to most of the bacterial strains. However, all of them were susceptible to the strain S-12 isolated from Japan. The cultivars S. J. 4, S. J. 5 and 
Akazaya were susceptible to all bacterial strains. The remaining 38 cultivars showed various responses, suggesting complicated genotypes of soybean cultivars for resistance to bacterial pustule.

In the soybean cultivars used in this experiment, nine groups ( I -1X) showing difference in susceptibility to six strains of X. c. pv. glycines could tentatively be recognized as shown in Table 2. Some cultivars showed different responses from the nine groups, suggesting that the grouping will become more complicated with increasing the number of bacterial strains used. From these results, it will be concluded that the resistance of the cultivars is possibly controlled by a number of genes. Among nine groups of soybean cultivars, the cultivars belong to group I were resistant to many bacterial strains.

Some soybean cultivars such as CNS (Hartwig and Lehman, 1951) Clark 63 (Chamberlain, 1962), Bragg, Bossier, Hampton-226, Hill, Hood, Lee, Pickett and Stuart having resistance derived from CNS (Pate1 et al., 1972) were reported to be resistant to bacterial pustule. The CNS type of resistance was reported to be expressed by a single major gene pair rpx (Hartwig and Lehman, 1951).

In our experiment, Clark 63 (Group I) were resistant to most strains used. These cultivars were only susceptible to strain S-12. The cultivars belonging to group Vlll were just opposite to group I in responses to bacterial strains.

The cultivars belonging to group IX were susceptible to all strains, suggesting absence of genes for resistance. Although none of the cultivars resistant to all bacterial strains was found in this experiment, the cultivars such as Harosoy, Clark 63 and TGX 297-192 C (Group I) were resistant to most of the strains used. Therefore, these cultivars will be useful for the breeding program of pustule resistance. However, cultivars will be infected when they are cultivated in the area where compatible bacterial strains are distributed. For example, these resistant cultivars will be susceptible in Japan where the compatible strain S-12 is distributed. Therefore, the accumulation of the genes for resistance of TGX 330-054 D, TGX 342-356 D, Shirome, Fukuyutaka, Papillon and Tamahomare to the group I cultivars will be needed.

Reverse reaction against some strains in the resistance was observed between group I and group WI, V and VII, VII and VI. These results clearly indicate that the resistance of soybean cultivars to X. c. pv. glycines is vertical resistance, though horizontal factors will join in some cases.

\section{ACKNOWLEDGEMENTS}

We wish to thank Prof. S. Matsumoto and Assist. Prof. T. Furuya, Department of Agronomy, Faculty of Agriculture, Prof. J. Inoue, Tropical Agricultural Research Center, Kyushu University, The National Institute of Agrobiological Resources (NIAR), Ibaraki, Japan and Assist. Prof. S. Prathuangwong and Mr. K. Amnoukij, Kasetsart University, Thailand, for providing soybean seeds and/or bacterial strains used in this study.

\section{REFERENCES}

Chamberlain, D. W. 1962 Reaction of resistant and susceptible soybean to Xanthomonas phaseoli var. sojense. Plant. Dis. Rept., 46 : 707-709 
Hartwig, E. E. and S. G. Legman 1951 Inheritance of resistance to bacterial pustule disease in soybeans. Agronomy J., 43 : 226-229

Jainkittivong, A., K. Tsuchiya., N. Matsuyama and S. Wakimoto 1989 Difference of Xanthomonas campestris strains isolated from soybean, cowpea and mung bean in pathogenicity and bacteriological properties. J.Fac. Agri., KyushuUniv., 33 (3•4) : 305-314

Lehman, S. G. and J. W. Woodside 1929 Varietal resistance of soybean to the bacterial pustule disease. J. of Agricultural research $39: 795-805$

Jindal, J. K., P. N. Pate1 and A. M. Khan 1981 Variability in xanthomonads of grain legumes II. pathogenic variability in Xanthomonas phaseoli var. sojense. Phytopath. Z., $100: 1-9$

Patel, P. N., J. K. Jindal and M. V. B. Rao 1972 Study on resistance in crop to bacterial disease in India III. Pustule resistance in soybean. Indian Phytopath., 25 : 168-171 